\title{
EFFECT OF CAFFEINE AND TANNINS ON CULTIVATION AND FRUCTIFICATION OF PLEUROTUS ON COFFEE HUSKS
}

\author{
Leifa Fan ${ }^{1,2}$; Andréa Thomaz Soccol²; Ashok Pandey ${ }^{3}$; Luciana Porto de Souza Vandenberghe²; \\ Carlos Ricardo Soccol ${ }^{2 *}$
}

\begin{abstract}
${ }^{1}$ Institute of Horticulture, Zhejiang Academy of Agricultural Sciences, Hangzhou, China; ${ }^{2}$ Laboratório de Processos Biotecnológicos, Departamento de Engenharia Química, Universidade Federal do Paraná, Curitiba, PR, Brasil; ${ }^{3}$ Biotechnology Division, Regional Research Laboratory, Trivandrum, India
\end{abstract}

Submitted: May 30, 2005; Returned to authors for corrections: March 09, 2006; Approved: July 20, 2006

\begin{abstract}
The objective of this work was to study the effect of caffeine and tannins on Pleurotus sp. cultivation and to evaluate the feasibility of using coffee husks as substrate for mushroom cultivation. Eight strains of $P$. ostreatus and two strains of $P$. sajor-caju were screened on a medium prepared from agar extract of coffee husk. Based on best mycelial growth and biomass production, the strain P. ostreatus LPB 09 was selected for detailed studies. With the increase of caffeine concentration, the mycelial growth and the biomass production decreased, and no growth was observed when concentration of caffeine was $2500 \mathrm{mg} / \mathrm{L}$. Furthermore, Pleurotus did not degrade the caffeine, but absorbed it. Tannin under $100 \mathrm{mg} / \mathrm{L}$ in the medium stimulated the growth of mycelia, but above $500 \mathrm{mg} / \mathrm{L}$ it had a negative effect. When the concentration reached $1000 \mathrm{mg} / \mathrm{L}$, the fungus still survived and showed a certain tolerance to it. No tannic acid was found in the mycelia, but its concentration decreased in the medium. This fact confirmed that Pleurotus had the capacity of degrading tannic acid. Fructification occurred after 20 days of inoculation and the biological efficiency reached about $97 \%$ after 60 days. Caffeine content in the husk after cultivation was reduced to $60.7 \%$ and tannins to $79.2 \%$. The results indicated the feasibility of using coffee husk without any pretreatment for the cultivation of Pleurotus.
\end{abstract}

Key words: cultivation, Pleurotus, caffeine, tannin, detoxification

\section{INTRODUCTION}

Coffee is one of the most important beverages of the world, and its yearly production is about one million tons in more than 50 countries $(13,21)$. Brazil is the largest producer of coffee in the world (13). In Brazil, coffee cherries are generally processed using the dry method, resulting in coffee husk, which is different from coffee pulp in composition of caffeine, tannin and polyphenois $(8,9,28)$. The caffeine and tannin content was about 1.3 and $10 \%$, respectively, in the coffee husk on dry weight basis $(8,9,21,28)$. Due to the presence of these toxic compounds, this organic solid residue has lead to the problem of environmental pollution $(5,8,9,21,28)$.
The edible mushroom Pleurotus sp. is considered a good alternative for protein rich food production in tropical countries $(7,16)$. Pleurotus also shows good ability in producing fruiting body and simultaneously reducing or degrading toxic substances present in the substrate $(7,11,29)$. Bermudez (3), Bernabe (4), Galzada (10), Lozano (14), Martinez (17,18), Mata (19), Soto $(25,26)$ and Tango (26) studied the production of Pleurotus with coffee pulp, obtaining good results. Barbosa (1) and Maziero (20) used coffee husk for the production of Pleurotus, but had no success. It was reported that mycelia were initially strong and vigorous, but after some days the growth was interrupted. Apparently, the concentration of toxic compounds was more concentrated in the coffee husk than

*Corresponding Author. Mailing address: Laboratório de Processos Biotecnológicos, Departamento de Engenharia Química, Universidade Federal do Paraná. 81531-970, Curitiba, PR, Brasil. Fax : (+5541) 266-0222. E-mail: soccol@ufpr.br 
that in the coffee pulp. Beaux and Soccol (2) utilised the coffee husk for growing Lentinus and reported poor mycelial growth in comparison to other substrates due to its high concentration of toxic compounds.

Tan (27) studied the effect of tannic acid (concentrations 500 to $1000 \mathrm{mg} / \mathrm{L}$ ) and caffeine ( 50 to $100 \mathrm{mg} / \mathrm{L}$ ) on the growth of L. edodes. The results demonstrated that both of them, under experimental concentrations, exercised a toxic effect on the growth of the mushroom L. edodes. Wong (30) demonstrated that the mushroom $P$. sajor-caju was capable of degrading tannin in coffee spent ground. This work was attempted to evaluate the effect of caffeine and tannin on Pleurotus and evaluate the feasibility of using coffee husk as substrate to cultivate edible mushroom Pleurotus and possibility of degrading its toxic compounds.

\section{MATERIALS AND METHODS}

\section{Microorganisms and screening}

Eight strains of Pleurotus ostreatus, LPB 01, 03, 08, 09, 22 , 23, 24, 31 and two Pleurotus sajor-caju, LPB 19 and 20 were used for screening purpose. The strains were maintained on potato-dextrose-agar (PDA) at $4^{\circ} \mathrm{C}$.

\section{Radial growth}

All the strains were grown in a medium containing the extract of coffee husk, which was prepared by cooking the coffee husks $\left(40 \mathrm{~g} . \mathrm{L}^{-1}\right)$ in distilled water for one hour, filtering and completing the volume to 1 litter with distilled water. Its $\mathrm{pH}$ was adjusted to 7, and after mixing with Agar (2\%), the medium was autoclaved at $121^{\circ} \mathrm{C}$ for 15 minutes. $15 \mathrm{~mL}$ of the medium were distributed in Petri dishes $(9 \mathrm{~cm}$ in diameter). The plate was inoculated with the fungal cultures as described by Soccol (24). The growth of mycelia was measured according to Soccol (24).

\section{Effect of caffeine and tannin}

The experiments were conducted in PDA plates with addition of different concentrations of caffeine and tannin using the selected strain. The concentrations of caffeine and tannin tested were: 30, 50, 100, 500, 1000, $2500 \mathrm{mg} . \mathrm{L}^{-1}$ and 100, 500, 1000, 5000, $10000 \mathrm{mg} . \mathrm{L}^{-1}$, respectively.

\section{Fructification and detoxification}

The moisture content of coffee husk solid medium was adjusted to 55 - $60 \%$, filled in plastic bags ( $20 \times 35 \mathrm{~cm}$ in size) and was autoclaved at $121^{\circ} \mathrm{C}$ for $1.5 \mathrm{~h}$. The bag was inoculated with the spawn and incubated in the dark at $24^{\circ} \mathrm{C}$. After 15 days, the bag was transferred to a lighted environment chamber ( $90 \%$ relative humidity) and plastic was removed to allow the aeration and lightning in order to facilitate fruiting body development.

\section{Spawn preparation}

A mixture of sawdust of Eucalyptus sp (80\%) and rice bran $(20 \%)$ was used for spawn preparation. The humidity was adjusted to $60 \%$ and then the mixture was filled in a glass jar of $500 \mathrm{~mL}$ capacity. After 20 days of incubation, the spawn was ready to be used for the inoculation of the solid substrate when the mixture turned totally to white.

\section{Biomass estimation}

Biomass was estimated by drying the biomass and measuring its dry weight according to Soccol (24).

\section{Biological Efficiency}

Biological efficiency (BE) is the ratio of the weight of fresh fruiting bodies and the initial weight of dry substrate, multiplied by 100 . It indicates the fructification ability of the fungus.

\section{Analysis of caffeine and tannin}

The spectrophotometric method, suggested by the manual of the Lutz Adolfo Institute (12), was used to analyse caffeine, using chloroform as solvent. The concentration of tannins was determined according to the method described in the manual of the Ministry of Agriculture (15). The concentration of caffeine and tannin in the mycelia and fruiting body was also analysed.

\section{RESULTS AND DISCUSSION}

\section{Selection of strains of Pleurotus}

Table 1 shows the behaviour of ten strains of Pleurotus sp. on the extract of coffee husk in relation to the radial growth of the

Table 1. Growth of Pleurotus strains on coffee husk extract medium*.

\begin{tabular}{|c|c|c|}
\hline Strains & $\begin{array}{l}\text { Velocity of radial } \\
\text { growth of mycelia } \\
\quad\left(\mathrm{mm} \cdot \text { day }^{-1}\right)\end{array}$ & $\begin{array}{c}\text { Biomass } \\
\text { (mg per dish) }\end{array}$ \\
\hline P. ostreatus LPB 09 & $9.68 \pm 1.67$ & $43.40 \pm 0.14$ \\
\hline P. ostreatus LPB 01 & $9.50 \pm 1.38$ & $40.10 \pm 1.84$ \\
\hline P. ostreatus LPB 22 & $9.34 \pm 1.53$ & $35.70 \pm 0.00$ \\
\hline P. ostreatus LPB 08 & $9.03 \pm 2.85$ & $31.90 \pm 4.80$ \\
\hline P. sajor-caju LPB 20 & $8.98 \pm 2.07$ & $24.50 \pm 2.30$ \\
\hline P.ostreatus LPB 23 & $8.95 \pm 1.80$ & $25.60 \pm 6.00$ \\
\hline P.ostreatus LPB 24 & $8.82 \pm 1.25$ & $18.80 \pm 0.56$ \\
\hline P. ostreatus LPB 31 & $8.80 \pm 1.22$ & $15.80 \pm 0.56$ \\
\hline P. sajor-саји LPB 19 & $8.12 \pm 1.81$ & $22.30 \pm 2.00$ \\
\hline P. ostreatus LPB 03 & $6.55 \pm 1.73$ & $14.20 \pm 0.35$ \\
\hline
\end{tabular}

*Temperature of incubation: $24^{\circ} \mathrm{C}$; initial $\mathrm{pH}$ : 7.0 ., results are the average of three measures. 
mycelia and the biomass production for nine days. Although all the strains grew well on this medium, P. ostreatus LPB 09 showed the best growth with high-density of mycelia growth, resulting in the highest radial growth velocity of $9.68 \mathrm{~mm}$. day ${ }^{-1}$ and a biomass of $43.4 \mathrm{mg}$.plate ${ }^{-1}$ in nine days. Table 2 presents the analysis of variance for radial growth velocity. This parameter did not show significant differences for all strains at $95 \%$ level. It is possible to say that the daily variation of radial growth was equal to all strains. After the Shapiro Wilk and F test (data not shown), it was possible to verify that the variances were not significantly different at $95 \%$ and $99 \%$. Consequently, it is possible to say that there are significant different at level 99\% for biomass production (Table 3). The Tukey test showed (Fig. 1) that LPB 09 has significant differences from other strains. Further investigations were then carried out using the strain P. ostreatus LPB 09.

Table 2. Analysis of variance of radial growth of Pleurotus strains.

\begin{tabular}{lccccc}
\hline $\begin{array}{l}\text { Summary } \\
\text { growth AV }\end{array}$ & Df & Sum Sq & Mean Sq & F value & $\operatorname{Pr}(>\mathrm{F})$ \\
\hline $\begin{array}{l}\text { Strains } \\
\text { Residuals }\end{array}$ & 9 & 21.513 & 2.390 & 0.9953 & 0.9953 \\
\hline
\end{tabular}

Table 3. Analysis of variance of biomass production of Pleurotus strains

\begin{tabular}{lccccc}
$\begin{array}{l}\text { Summary } \\
\text { growth AV }\end{array}$ & Df & Sum Sq & Mean Sq & F value & $\operatorname{Pr}(>\mathrm{F})$ \\
$\begin{array}{l}\text { Strains } \\
\text { Residuals }\end{array}$ & 9 & 27779.68 & 308.85 & 42.557 & $4.218 \mathrm{e}-11 * * *$ \\
\hline
\end{tabular}

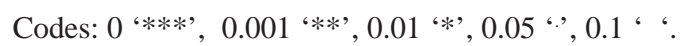

\section{Effect of caffeine}

Table 4 demonstrates the effect of different concentrations of caffeine on the cultivation of $P$. ostreatus LPB 09 in relation to the mycelial growth and biomass production on PDA after six days of culture. The mycelia growth and the biomass production decreased with the increase of caffeine concentration in the medium. Growth was completely inhibited when the concentration of caffeine in the medium was 2500 mg.L $L^{-1}$. It was also possible to observe that Pleurotus degraded caffeine partially. Pleurotus was not capable to degrade completely the caffeine, but absorb it partially.

The absorption of caffeine by Pleurotus mycelia was not reported in the literature. Tan (27) cultivated L. edodes using different concentrations of caffeine in the medium.

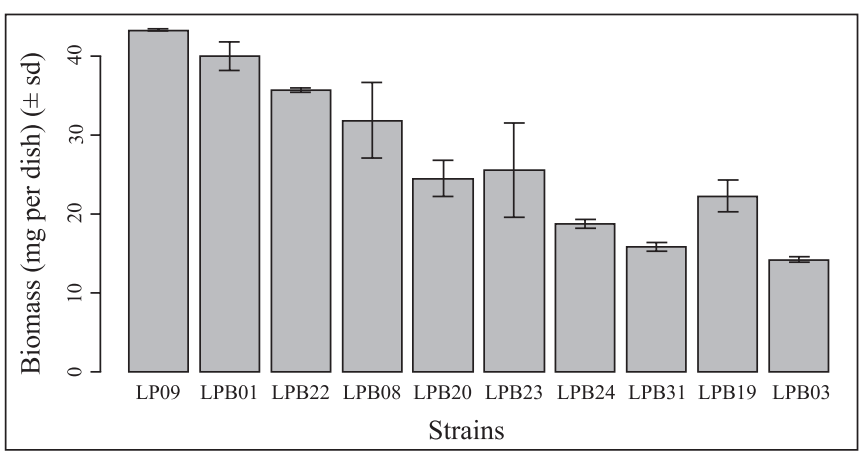

Figure 1. Biomass production of different strains of Pleurotus.

Caffeine concentrations of 50 to $100 \mathrm{mg} . \mathrm{L}^{-1}$ had positive effect on mycelial growth, but a concentration of $300 \mathrm{mg} . \mathrm{L}^{-1}$ or above inhibited mycelial growth and fructification.

\section{Effect of tannins}

Table 5 shows the effect of different concentrations of tannic acid on the mycelial growth of $P$. ostreatus LPB 09 in PDA after seven days of culture. Above $500 \mathrm{mg} . \mathrm{L}^{-1}$ it had a negative effect. When the concentration reached $1000 \mathrm{mg} . \mathrm{L}^{-1}$, the fungus still survived and showed a certain tolerance to it. No tannic acid was found in the mycelia, but decreased in the medium, confirming that the fungus had the capacity of degrading tannic acid.

Wong et al. (30) mentioned that the P. sajor-caju was capable to degrade the tannins in coffee spent ground. Cai $e t$ al. (6) observed that the derived monomers of lignin in low concentration $\left(100 \mathrm{mg} . \mathrm{L}^{-1}\right)$ were capable to stimulate the growth of Pleurotus. Tan (27) studied the effect of tannic acid (from 500 to $1000 \mathrm{mg} . \mathrm{L}^{-1}$ ) on the growth of $L$. edodes. The results showed that these concentrations exerted toxic effects.

Table 4. Caffeine effect on the mycelial growth of P. ostreatus LPB 09 in PDA after 6 days and its accumulation in the mycelia.

\begin{tabular}{|c|c|c|c|c|}
\hline $\begin{array}{l}\text { Concentration } \\
\text { of caffeine } \\
\text { (mg. } \mathrm{L}^{-1} \text { of } \\
\text { medium) }\end{array}$ & 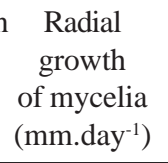 & $\begin{array}{c}\text { Biomass } \\
\text { (mg per dish) }\end{array}$ & $\begin{array}{l}\text { Concentration } \\
\text { caffeine in } \\
\text { mycelia } \\
\left(\mathrm{mg} \cdot \mathrm{g}^{-1}\right)\end{array}$ & $\begin{array}{l}\text { Final } \\
\text { concentration } \\
\left(\mathrm{mg} \cdot \mathrm{L}^{-1}\right)\end{array}$ \\
\hline 0 & $13.12 \pm 0.21$ & $55.32 \pm 1.43$ & 0 & 0 \\
\hline 30 & $12.56 \pm 0.43$ & $53.44 \pm 2.36$ & 0.0657 & 0 \\
\hline 50 & $12.23 \pm 0.26$ & $52.76 \pm 1.28$ & 0.1342 & 4.02 \\
\hline 100 & $11.02 \pm 0.32$ & $47.29 \pm 1.55$ & 3.7866 & 58.00 \\
\hline 500 & $8.13 \pm 0.42$ & $32.56 \pm 2.35$ & 9.1625 & 399.49 \\
\hline 1000 & $4.52 \pm 0.41$ & $12.37 \pm 2.44$ & 13.8527 & 860.02 \\
\hline 2500 & 0 & 0 & l & / \\
\hline
\end{tabular}

“/”: no analysis. 
Table 5. Effect of tannic acid on the mycelial growth of $P$. ostreatus LPB 09 in PDA after 7 days and its degradation.

\begin{tabular}{ccccc}
\hline $\begin{array}{c}\text { Concentration } \\
\text { of tannic acid } \\
\left(\mathrm{mg} . \mathrm{L}^{-1}\right)\end{array}$ & $\begin{array}{c}\text { Radial } \\
\text { growth } \\
\text { of mycelia } \\
\left(\mathrm{mm}_{\text {day }}{ }^{-1}\right)\end{array}$ & $\begin{array}{c}\text { Biomass } \\
(\mathrm{mg} \text { per dish) }\end{array}$ & $\begin{array}{c}\text { Concentration } \\
\text { tannic acid } \\
\text { in mycelia } \\
\left(\mathrm{mg} . \mathrm{L}^{-1}\right)\end{array}$ & $\begin{array}{c}\text { Final } \\
\text { concentration } \\
\text { of tannic acid } \\
\text { in the medium } \\
\left(\mathrm{mg} . \mathrm{L}^{-1}\right)\end{array}$ \\
\hline 0 & $11.29 \pm 0.11$ & $50.12 \pm 1.55$ & 0 & 0 \\
100 & $11.76 \pm 0.23$ & $52.84 \pm 1.76$ & 0 & 29.63 \\
500 & $8.71 \pm 0.00$ & $43.06 \pm 1.21$ & 0 & 277.09 \\
1000 & $2.72 \pm 0.24$ & $10.20 \pm 1.12$ & 0 & 429.45 \\
5000 & $1.58 \pm 0.34$ & $3.27 \pm 1.56$ & $/$ & $/$ \\
10000 & $0.82 \pm 0.11$ & $1.33 \pm 0.12$ & $/$ & $/$ \\
\hline
\end{tabular}

"/": no analysis.

Statistical analyses of the results of caffeine and tannins concentrations effect on Pleurotus growth were conducted. However, it was not possible to apply the analysis of variance to the data in order to compare the differences between them. The study was based in progressive concentrations of caffeine and tannins and the results are not correlated with the applied concentrations.

\section{Fructification of Pleurotus on coffee husk}

The first fructification started after 20 days of inoculation (5 days after opening of the plastic bag); the second, third, and four flashes were harvested during 60 days of cultivation. The fructification is shown in Fig. 2. The total biological efficiency was $96.5 \%$. Martinez (16) obtained a biological efficiency of $175.8 \%$ on drained coffee pulp in Mexico. The

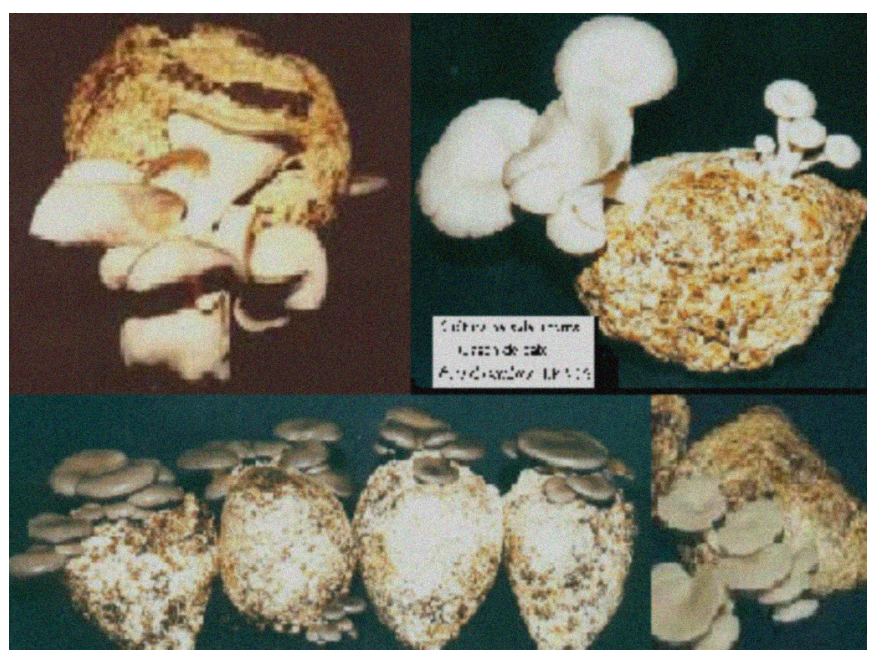

Figure 2. Fructification of P. ostreatus LPB 09 on coffee husk. results on Brazilian coffee husk were lower than those obtained by Martinez.

\section{Coffee husk detoxification}

Table 6 shows that the concentration of caffeine in the coffee husk was reduced to $60.7 \%$ after colonisation and fructification of Pleurotus. Analysis of fruiting body of this mushroom showed a concentration of $0.197 \mathrm{mg} \cdot \mathrm{g}^{-1}$ of dry fruiting body. It confirmed that Pleurotus did not completely degrade the caffeine, but it was partially accumulated in the mushroom. The tannin concentration was also reduced significantly in the husk, reaching a reduction of $79.17 \%$. But in the fruiting bodies, no tannin was found, which suggested that the mushroom was capable of completely degrading the tannin present in the coffee husk.

Table 6. Change of caffeine and tannin content before and after growing of $P$. ostreatus LPB 09 in coffee husk.

\begin{tabular}{cccc}
\hline Component & $\begin{array}{c}\text { Initial content } \\
\left(\mathrm{mg} \cdot \mathrm{g}^{-1}\right)\end{array}$ & $\begin{array}{c}\text { Final content } \\
\left(\mathrm{mg} \cdot \mathrm{g}^{-1}\right)\end{array}$ & $\begin{array}{c}\text { Reduction } \\
\%\end{array}$ \\
\hline Caffeine & $0.65 \pm 0.12$ & $0.197 \pm 0.093$ & -60.69 \\
Tannin & $3.65 \pm 0.21$ & $0.76 \pm 0.14$ & -79.17 \\
\hline
\end{tabular}

\section{CONCLUSIONS}

This study demonstrated that the strain $P$. ostreatus LPB 09 was capable to produce the fruiting body on coffee husks, even with high concentrations of caffeine and tannin in the medium. Coffee husk was found to be an excellent substrate for mushroom cultivation, especially $P$. ostreatus. Fructification of mushroom reduced $60.69 \%$ of caffeine present in the coffee husk. However, the fungus was not capable of completely degrading caffeine, which was partially accumulated in the mycelia and in the fruiting bodies. On the contrary, tannin was degraded, with a reduction of $79.19 \%$ in the coffee husk. The final solid residue, after the fructification of the mushroom, could be an excellent product for animal feeding, due to its content of protein $(9.62 \%)$.

\section{ACKNOWLEDGEMENTS}

Financial assistance from the European Union (grant No: INCO DC: IC18*CT 970185) and EMBRAPA (Projeto No: 07.1.99.057) is gratefully acknowledged. Fan Leifa and C. R. Soccol would like to thanks CNPq for a scholarship under the conditions of Scientific Productivity scheme. 


\section{RESUMO}

\section{Efeito da cafeína e taninos no cultivo e frutificação de Pleurotus em casca de café}

O objetivo do presente trabalho foi estudar o efeito da cafeína e taninos sobre o desenvolvimento do fungo Pleurotus sp. e avaliar a possibilidade do uso da casca de café como substrato no seu cultivo. Oito cepas de P. ostreatus e duas cepas de $P$. sajor-caju foram selecionadas em um meio à base de extrato aquoso de casca de café e Agar. A cepa $P$. ostreatus LPB 09 foi escolhida para estudos posteriores com base na velocidade de crescimento do micélio e produção de biomassa. O estudo do desenvolvimento do cogumelo em meio com diferentes concentrações de cafeína mostrou que o aumento da concentração da mesma influencia negativamente crescimento. A partir de uma concentração de cafeína de $2500 \mathrm{mg} / \mathrm{L}$ não foi observado crescimento. Observou-se ainda que o Pleurotus não degradou a cafeína, mas a absorveu. Os taninos em concentração abaixo de 100 $\mathrm{mg} / \mathrm{L}$ no meio estimularam o crescimento do micélio, no entanto acima de $500 \mathrm{mg} / \mathrm{L}$ mostraram efeito negativo. Quando a concentração de taninos atingiu $1000 \mathrm{mg} / \mathrm{L}$, o cogumelo ainda sobreviveu e mostrou uma certa tolerância. O ácido tânico não foi encontrado no micélio, o que confirma que o Pleurotus possui a capacidade de degradá-lo. A frutificação ocorreu após 20 dias de inoculação e a eficiência biológica atingiu $97 \%$ em 60 dias. O conteúdo de cafeína da casca de café foi reduzido para $60.7 \%$ e o de taninos para $79.2 \%$. Os resultados mostram boas perspectivas para o cultivo de Pleurotus utilizando casca de café como substrato sem a necessidade de qualquer pré-tratamento.

Palavras-chave: cultivo, Pleurotus, cafeína, taninos, detoxificação

\section{REFERENCE}

1. Barbosa, M.C. Aproveitamento de resíduos de cassava de mandioca para produção de Pleurotus. Curitiba, 1996, 180p. (Master of Science Thesis. UFPR).

2. Beaux, M.R.; Soccol, C.R. Cultivo do fungo comestível Lentinula edodes em resíduos agroindustriais do Paraná através do uso de fermentação no estado sólido. Bol. do CEPPA, 14, 11-21, 1996.

3. Bermudez, R.C.; Traba, J.A. Produccion de Pleurotus sp cfr. Florida sobre residuales de la agroindustria cafetalera en Cuba Micol. Neotropical Aplic., 7, 47-50, 1994.

4. Bernabe, G.T.; Dominguez, M.S.; Bautista, S.A. Cultivo del hongo comestible Pleurotus ostreatus var. Florida sobre fibra de coco y pulpa de café. Ver. Mex. Micol., 9, 13-18, 1993.

5. Bressani, R. Antiphysiological factors in coffee pulp. Coffee Pulp: Composition, Technology and Utilization, IDRC Pub., 108, 1979.

6. Cai, Y.J.; Buswell, J.A.; Chang, S.T. Effect of lignin-derived phenolic monomers on the growth of the edible mushrooms L. edodes, $P$. sajor-caju, V. volvacea. W. J. Microbiol. Biotechnol., Oxford, 9, 503-507, 1993.

7. Chang, S.T. Edible mushroom and their cultivation, CRC Press, Inc., Florida, 1989.
8. Leifa, F.; Pandey, A.; Soccol, C.R. Production of mushrooms on Brazilian coffee industry residues. In: Sera, T.; Soccol, C.R.; Pandey, A.; Roussos, S.(eds). Coffee Biotechnology and Quality. Kluwer Academic Publishers, 2000, p.427-436.

9. Leifa, F.; Pandey, A.; Mohan, R.; Soccol, C.R. Use of Various coffee Industry Residues for the production of Pleurotus ostreatus in Solid State Fermentation Acta Biotechnol., 20(1), 41-52, 2000.

10. Galzada, J.F.; Leon, R.; Arriola, M.C.; Rolz, C. Growth of mushroom on wheat straw and coffee pulp: strain selection. Biol. Wastes, 20, 217-226, 1987

11. Hadar, Y. Biodegradation of lignocellulosic agricultural wastes by Pleurotus ostreatus, J. Biotechnol., 30, 133-139, 1993.

12. Instituto Adolfo Lutz (IAL). Métodos químicos e físicos para análise de alimentos Normas Analíticas de Instituto Adolfo Lutz 3rd, São Paulo, IMESP, 1985, p.189-192, 195-196.

13. International Coffee Organization-ICO, Total production of exporting members. http://www.ico.org/proddoc.htm/, 1998.

14. Lozano, J.C. Produccion comercial del champinon (Pleurotus ostreatus) en pulpa de coffee. Fitopatol. Colombiana, 14, 42-47, 1990.

15. Ministério da Agricultura do Brazil, Secretaria Nacional de Defesa Agropecuária-Laboratório de Referência Vegetal Metodologia de Análise de Bebidas e Vinagres, 1986.

16. Martinez, C.D.; Quirarte, M. Prospects of growing edible mushroom on agro-industrial residues in Mexico, Boletin de la Sociedad Mexicana de Micologia, 19, 207-219, 1984.

17. Martinez, C.D.; Soto, C.; Guzman, G. Cultivo de Pleurotus ostreatus en pulpa de café com paja como substrato. Rev. Mex. de Micol., 1, 101-108, 1985

18. Martinez, C.D.; Morales, P.; Sobal, M. Cultivo de Pleurotus ostreatus sobre bagazo de cana enriquecido com pulpa de café o paja de cebada. Micol. Neotropical Aplic., 3, 49-52, 1990.

19. Mata, G.; Gaitan Hernandez R. Advances in shiitake cultivation on coffee pulp Rev. Iberoamericana Microl., 11, 90-91, 1994.

20. Maziero, R. Substratos alternativos para o cultivo de Pleurotus sp. São Paulo, 1990. (Master Science Thesis, Faculdade de Ciências da USP).

21. Pandey, A.; Soccol, C.R.; Nigam, P.; Brand, D.; Mohan, R.; Roussos, S. Biotechnological potential of coffee pulp and coffee husk for bioprocesses Bioch. En. J.l, 6, 153-162, 2000.

22. Secretaria de Estado da Agricultura e Abastecimento do Paraná, Boletim de Desenvolvimento do Agronegócio no Paraná, Maio, 1998.

23. Soccol, C.R. Aplicações da fermentação no estado sólido na valorização de resíduos agroindustriais. França-Flash Agricultura, 4, 3-4, 1995.

24. Soccol, C.R. Contribuição ao estudo da fermentação no estado sólido em relação com a produção de ácido fumárico. Biotransformação de resíduo sólido de mandioca por Rhizopus e Basidiomacromicetos do gênero Pleurotus Curitiba, 1994, p.280. (Tese de Professor Títular. UFPR).

25. Soto, C. La produccion los hongos comestibles sobre la pulpa de café en la region de Xalapa, Veracruz durante 1985-1986. Rev. Mex. Micol., 2,437-440, 1986.

26. Soto, C.; Martinez, C.D.; Morales, P.; Sobal, M. La pulpa de café seccada alsol, como una forma de alaccnamiento para el cultivo de Pleurotus ostreatus. Rev. Mex. Micol., 3, 133-136, 1987.

27. Tan, Y.H.; Chang, S.T. Effect of growth regulators, enzyme inhibitors and stimulatory additives on the vegetative development and fructification of $L$. edodes. Proceedings of the twelfth international congress on the science and cultivation of edible fungi. September, Braunschweig, Germany, 1987.

28. Tango, J.S. Utilização industrial do café e dos seus subprodutos. Boletim do Instituto de Tecnologia de Alimentos-ITAL, São Paulo, Brasil. 28, 49-73, 1971.

29. Thiclke, C. Cultivation of edible fungi on coffee grounds, Mushroom Sci., 12, 337-343, 1989.

30. Wong, Y.S.; Wang, X. Degradation of tannins in spent coffee grounds by Pleurotus sajor-caju. World J. Microbiol. Biotechnol., Oxford, 7(5), 573-574, 1991. 